\title{
After COP24 Conference in Katowice - the role of the Institute of Meteorology and Water Management - National Research Institute in connection of hydrological and meteorological measurements and observations with climate change adaptation actions
}

During the night of the $14^{\text {th }}$ December 2018, the difficult but extremely important $24^{\text {th }}$ Conference of the Parties to the United Nations Framework Convention on Climate Change (COP 24) came to an end. The aim of the UN climate summit in Katowice was to develop a Rulebook, i.e. a "road map", for the implementation of the Paris Agreement of 2015, which aimed at limiting the global rise in temperature.

The main objective of the Paris Agreement is to strengthen the global response to the threat of climate change by maintaining a global temperature rise in this century much less than $2^{\circ} \mathrm{C}$ above pre-industrial levels, and to continue efforts to limit the temperature rise to $1.5^{\circ} \mathrm{C}$. To achieve these goals, appropriate mobilization and funding, a new technological framework and strengthened capacity building must be established. This acts to support the activities of developing and vulnerable countries, in accordance with their own national goals. The agreement also provides for an improved transparency framework for the actions taken and the provided support.

In order for the Paris Agreement to become fully operational, a work program for the development of principles, procedures and guidelines for a wide range of issues was launched in Paris. In 2016, the Parties began to cooperate with each other within subsidiary bodies (APA - Ad Hoc Working Group on the Paris Agreement, SBSTA - Subsidiary Body for Scientific and Technological Advice and SBI - Subsidiary Body for Implementation) and in various bodies. The COP, the official conference of the Parties of the Paris Agreement (CMA), took place for the first time in 2016 in connection with the COP 22 in Marrakech and adopted the first two decisions. One of them - the work program, in accordance with the assumption, was completed in 2018 during COP 24 in Katowice, and the second one which aimed at developing a mechanism for the exchange of experiences in the field of adaptation.

One of the fundamental elements of the Paris Agreement is the group of activities undertaken in the area of adaptation. The implementation of these activities at the national level would not be possible without meteorological and hydrological monitoring carried out by the Institute of Meteorology and Water Management - National Research Institute (IMGW-PIB), under the Water Law Act, as a national hydrological and meteorological survey.
The lack of a common position of experts emphasizes the importance and necessity of conducting regular analysis of the state of the environment, based on a unified methodology. Conducting measurements and observations by the IMGW-PIB covers all physical processes taking place in the atmosphere and hydrosphere. In particular, these processes are important in planning activities that slow down the processes of climate change, for the adaptation to existing changes. The methodology used for meteorological and hydrological analysis is reflected in the international schemes that create an integrated system of data collection, transmission and processing.

Coherent systems and methods for conducting measurements and observations, as well as independent analysis conducted in many countries, allow for the creation of scenarios and models of climate change, the determination of trends and reveal the need to immediately implement measures of the Paris Agreement. As a result of the work of scientists in the field of climate change, on the basis of long-term measurements and observation sequences, from Member countries of the World Meteorological Organization (WMO), a Special Report on the impact of climate change on $1.5^{\circ} \mathrm{C}$ (SR15) was adopted. It states that global warming is likely to increase to $1.5^{\circ} \mathrm{C}$ above pre-industrial levels between 2030 and 2052, if no action is undertaken and the insulation will continue to grow at the currently observed rate. SR 15 summarizes the impact of $1.5^{\circ} \mathrm{C}$ warming (equivalent to $2.7^{\circ} \mathrm{F}$ ) on the functioning of the planet, and outlines the necessary steps to limit global warming.

A positive evaluation of the system for monitoring climate change and its effectiveness will be possible only when it will be possible to plan the appropriate adaptation, elimination or reduction of risks by all countries. To carry out such an assessment, it is necessary to obtain historical, current and forecasted hydrological and meteorological information on the changing environmental conditions. This is provided by the national survey, which is cooperating with the crisis management sector in the country.

Currently, the IMGW-PIB continuously provides government authorities, the society and the national economy with up-to-date information within three main systems: the measurement and observation system (approximately 1750 hydrological and meteorological measurement stations); the data transfer system; and the data processing, forecasting and warning system. 
IMGW-PIB performs regular measurements carried out in accordance with the WMO guidelines throughout Poland, based on the network of hydrological and meteorological measurement stations. These measurements contribute to the development of methods of warning against dangerous phenomena, and also allows for the development of science in the area of unprecedented or unrecognized processes and phenomena.

The implementation of the Paris Agreement and the Katowice Climate Package in Poland would not be possible without the proper mobilization and allocation of key resources in the decision-making process. In the case of extreme phenomena, which have demonstrated a significant increase in recent, the hydrological and meteorological protection system play the key role in the interaction with the crisis management system. Experiences with meteorological and hydrological hazards that have hit Poland in the $21^{\text {st }}$ century have demonstrated the need to strengthen activities in the area of adaptation, as well as the possibilities of their detection in order to effectively use information by entities responsible for the security of the society.

Measurement data collected, processed and made available by IMGW-PIB significantly improve the ability of the early identification and assessment of potential risks through the usage of modern tools, thus developing new solutions for the detection of extreme weather phenomena.

Correct and reliably performed tasks of the national hydrological and meteorological survey provide public administration bodies, as well as the whole society, with up-to-date data on the state of the atmosphere and hydrosphere, forecasts and warnings in both daily and threat situations.

Conducting constant, reliable, unified monitoring using the hydrological and meteorological survey and services is one of the basic tools that provide data and information on the environmental impact of forecasted climate change for Poland. This leads to the planning of activities that minimize the negative effects of climate change and paves the way to the full implementation of the Paris Agreement.

Marta Barszczewska, Ksawery Skąpski

Institute of Meteorology and Water Management - National Research Institute

\section{Bibliography}

Dz.U. $2005 \mathrm{Nr}$ 187, poz. 1568, Ordinance of the Council of Ministers of September $13^{\text {th }}, 2010$ on granting the Institute of Meteorology and Water Management in Warsaw the status of a national research institute, (in Polish), ISAP, Sejm RP

Dz.U. 2008 Nr 225, poz. 1501, Ordinance of the Minister of the Environment of November $6^{\text {th }}, 2008$ on standard procedures for collecting and processing information by the national hydrological and meteorological survey and national hydrogeological survey, (in Polish), ISAP, Sejm RP

Hoegh-Guldberg O., Jacob D., Taylor M., Bindi M., Brown S., Camilloni I., Diedhiou A., Djalante R., Ebi K.L., Engelbrecht F., Guiot J., Hijioka Y., Mehrotra S., Payne A., Seneviratne S.I., Thomas A., Warren R., Zhou G., 2018, Impacts of $1.5^{\circ} \mathrm{C}$ global warming on natural and human systems, [in:] Global warming of $1.5^{\circ} \mathrm{C}$. An IPCC Special Report on the impacts of global warming of $1.5^{\circ} \mathrm{C}$ above pre-industrial levels and related global greenhouse gas emission pathways, in the context of strengthening the global response to the threat of climate change, sustainable development, and efforts to eradicate poverty, V. Masson-Delmotte, P. Zhai, H.-O. Pörtner, D. Roberts, J. Skea, P.R. Shukla, A. Pirani, W. Moufouma-Okia, C. Péan, R. Pidcock, S. Connors, J.B.R. Matthews, Y. Chen, X. Zhou, M.I. Gomis, E. Lonnoy, T. Maycock, M. Tignor, and T. Waterfield (eds.), Intergovernmental Panel on Climate Change, 175-311, in press

IPCC, 2007, Climate change 2007: Impacts, adaptation and vulnerability. Contribution of Working Group II to the Fourth Assessment Report of the Intergovernmental Panel on Climate Change, M.L. Parry, O.F. Canziani, J.P. Palutikof, P.J. van der Linden, C.E. Hanson (eds.), Cambridge University Press, Cambridge, UK, 976 pp.

Kozłowska-Szczęsna T., Limanówka D., Niedźwiedź T., Ustrnul Z., Paczos S., 1993, Thermal characteristic of Poland, (in Polish), Zeszyty Instytutu Geografii i Przestrzennego zagospodarowania PAN, 18, 81 pp.

Kurowska-Łazarz R., Szulc W., Woźniak B., Piotrowska M., Drożdżyńska J., 2015, Vademecum Meteorological measurement and observations, IMGW-PIB, Warsaw, 69 pp.

Szumiejko F., Wdowikowski M., 2016, IMGW-PIB Monitor as a source of information on dangerous meteorological and hydrological phenomena for crisis management needs, Obronność. Zeszyty Naukowe Wydziału Zarządzania i Dowodzenia Akademii Sztuki Wojennej, 2 (18), 209-226

UNFCCC, 2016, Report of the Conference of the Parties on its twenty-first session, held in Paris from 30 November to 13 December 2015. Addendum. Part two: Action taken by the Conference of the Parties at its twenty-first session, 1/CP.21 Adoption of the Paris Agreement, FCCC/CP/2015/10/Add.1, 21-36 